\title{
Tumor Specific Oligomeric Forms of Nucleophosmin
}

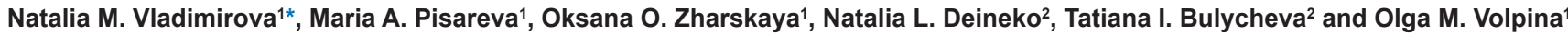 \\ ${ }^{1}$ Shemyakin-Ovchinnikov Institute of Bioorganic Chemistry Russian Academy of Sciences, ul. Miklukho-Maklaya 16/10, Moscow, 117997 Russia \\ ${ }^{2}$ Hematology Research Center, Russian Ministry of Public Health, Novyi Zykovskii pr. 4a, Moscow, 125167 Russia
}

\begin{abstract}
Background: According to recent data malignization of cells is accompanied not only by overexpression of protein B23/nucleophosmin, but also by formation of its new structural forms including unusual oligomers. The aim of this study was to evaluate the structural features of nucleophosmin in tumor cells.
\end{abstract}

Materials and methods: Structural state of nucleophosmin was analyzed in different human tumor cells (HeLa, NGP, Hep G2, Osa-CL, Jurkat, Ramos, K-562) and human lymphocytes stimulated to proliferate by phytohemagglutinin. Commercially available monoclonal antibodies and new obtained by us antipeptide antibodies were used for analysis of monomer-oligomer state of nucleophosmin by immunochemical method and for determination of intracellular localization of monomers and oligomers by immunocytochemical method.

Results: We revealed unusual SDS-resistant oligomeric forms of nucleophosmin in tumor cells of different type. Using protein chemistry strategy we showed the presence of truncated B23 isoforms in HeLa cells and their ability to form SDS-resistant oligomers. For the first time we created antipeptide antibodies which allowed differentiate monomeric and oligomeric nucleophosmin forms in tumor cells. Using these antibodies we showed different intracellular localization of monomers and oligomers in tumor cells.

Conclusions: We propose that formation of SDS-resistant oligomeric forms of nucleophosmin is a common feature of human tumor cells and their detection with described antipeptide antibodies may be used for tumor diagnostics.

Keywords: Monomer-oligomer state; Nucleophosmin; SDS-resistant oligomers; Antipeptide antibodies; Tumor cells

\section{Introduction}

Nucleophosmin (protein B23, NPM 1) belongs to the family of nuclear chaperones, nucleoplasmins. Nucleophosmin was initially found in nucleoli, it was named a key nucleolar protein involved in ribosome biogenesis. Today it is known that nucleophosmin is localized not only in nucleolus but also in nucleoplasm and cytoplasm [1] and plays a significant role in many processes such as cell proliferation, regulation of cell cycle, apoptosis and carcinogenesis [2]. The role of nucleophosmin in carcinogenesis is very intricate and diverse. Nucleophosmin is considered as an oncomarker and possible protooncogen participating in regulation of the activity and stability of tumor suppressor proteins Arf and p53 [2-4].

Such polyfunctionality of nucleophosmin is due to both the protein structure with complex domain organization [5-7] and existence of a family of its numerous structural forms: isoforms B23.1 and B23.2, a lot of forms resulting in posttranslational modifications of isoforms, homo- and heterooligomers of different nucleophosmin forms $[7,8]$. Only the long B23.1 isoform contains unique C-terminal domain and namely this domain involves a nucleolar localization signal sequence crucial for nucleic acid binding. For this reason isoform B23.1 is mainly localized in RNA-rich nucleolus. Isoform B23.2 non containing $\mathrm{C}$-terminal domain is mainly localized in nucleoplasm and cytoplasm. The properties of the monomers and the oligomers are also different. The most of the functions such as chaperoning, RNA-binding etc. are realized by oligomers and only DNA-binding activity is realized by B23.1 monomer $[7,8]$.

The most complicated situation is typical for tumor cells in which not only overexpression of nucleophosmin leading to a decrease in cell sensitivity to apoptosis is observed, but also takes place formation of its new structural forms [2,3]. It was shown that the gene of nucleophosmin most frequently underwent modifications (mutations, deletions, translocations) during malignant blood disorders $[9,10]$. The mutations in C-terminus of B23.1 isoform represent the most common genetic alteration so far identified in patients with acute myeloid leukemia with normal karyotype. The mutant isoforms lose nucleolar localization signaling sequence and have abnormal cytoplasmic localization. In a number of hematological malignancies nucleophosmin gene is fused with different partner genes, such as genes of anaplastic lymphoma kinase, receptor of retinoic acid $\alpha$ and myeloid leukemia factor $1[9,10]$. Fused and mutant forms change the content and the localization of the wild-type nucleophosmin through forming of its heterooligomers. In solid tumors (liver, breast, ovary, prostate, large bowel, and stomach cancer), nucleophosmin is overexpressed as well $[11,12]$ but its structural state is less studied. It is only known that patients with hepatocellular carcinoma have a truncated (by about 1 $\mathrm{kDa}$ ) form of nucleophosmin making oligomers, which are cleaved by granzyme B and detected by SDS-PAGE [12]. Such oligomers, termed by the authors as SDS-resistant, have not been found in normal and cirrhotic liver cells. At the same time, oligomeric forms of B23 exist

*Corresponding author: Dr. Natalia Vladimirova, Shemyakin-Ovchinnikov Institute of Bioorganic Chemistry Russian Academy of Sciences, ul. Miklukho-Maklaya 16/10, 117997 Moscow, Russia, E-mail: vla.ibch@mail.ru

Received September 30, 2011; Accepted October 16, 2011; Published October 18, 2011

Citation: Vladimirova NM, Pisareva MA, Zharskaya OO, Deineko NL, Bulycheva TI, et al. (2011) Tumor Specific Oligomeric Forms of Nucleophosmin. JJ Cancer Sci Ther 3: 205-212. doi:10.4172/1948-5956.1000090

Copyright: (C) 2011 Vladimirova NM, et al. This is an open-access article distributed under the terms of the Creative Commons Attribution License, which permits unrestricted use, distribution, and reproduction in any medium, provided the original author and source are credited. 
in normal and cirrhotic liver cells and are visible under "native" gel electrophoresis (without SDS). We and other authors [13,14] have found SDS-resistant nucleophosmin oligomers also in human cervical carcinoma (HeLa) cells. In our recent work [15] we have developed a strategy using the arsenal of protein chemistry methods for isolation and structural analysis of nucleophosmin forms functioning in $\mathrm{HeLa}$ cells. We applied this strategy for structural analysis of nucleophosmin in different tumor cells in this work.

The purpose of the present work is to evaluate monomeroligomer state of nucleophosmin in tumor cells of different types, to reveal abnormal tumor specific forms and to develop instruments for detection and characterization of these forms including unusual oligomers of nucleophosmin.

\section{Materials and Methods}

\section{Materials}

The following materials were used in this work: $10 \%$ fetal bovine serum (FBS), DMEM culture medium (HyClone, USA); gentamicin, penicillin, streptomycin (Gibco, UK); versene solution (Paneco, Russia); calibration standard proteins (SDS-6H) ), horseradish peroxidase-conjugated goat antibodies to rabbit or to mouse (IgG + IgM), paraformaldehyde (PFA), EDTA disodium salt, 3,3'-diaminobenzidine (DAB), BSA, OVA, KLH (Keyhole Limpet Hemocyanin), HISTOPAQUE-1077 (Sigma, USA); CFA (complete Freund's adjuvant) and IFA (incomplete Freund's adjuvant) (MP, Biomedicals, USA); CNBr-activated Sepharose 4B (GE healthcare, Sweden); reagents for electrophoresis and blotting (BioRad, USA); reagents for the peptide synthesis, derivatives of amino acids (Merck, Germany; Fluka and Senn Chemicals, Switzerland); Immobilon-NC and -P membranes, pore diameter $0.45 \mu \mathrm{m}$ (Millipore, USA); RPMI 1640 (ISN, UK); phytohemagglutinin (PHA, Difco, UK); Mowiol (Hoechst, USA); fluorescein isothiocyanate (FITC)-conjugated goat antibodies to rabbit or to mouse (IgG + IgM) (Sorbent, Russia). Other reagents were domestic products of chemical or high purity grade.

\section{Cell cultures}

Human cell cultures HeLa (cervical carcinoma), NGP (neuroblastoma), Hep G2 (hepatocellular carcinoma), Osa-CL (osteocarcinoma) and mouse cell culture NIH/3T3 (embryonic fibroblasts) were grown in culture flasks or on cover slips as a monolayers in Dulbecco's modified Eagle's medium (DMEM) supplemented with $10 \% \mathrm{FBS}$, penicillin $(10 \mu \mathrm{g} / \mathrm{ml})$ and streptomycin $(10 \mu \mathrm{g} / \mathrm{ml})$ at $37^{\circ} \mathrm{C}$ in $5 \% \mathrm{CO}_{2}$ humidified incubator at $37^{\circ} \mathrm{C}$. Suspension cell cultures Jurkat (acute T-cell leukemia), Ramos (B-chronic lymphatic leukemia) and $\mathrm{K}-562$ (chronic myeloid leukemia) were grown in RPMI 1640 medium supplemented with $10 \% \mathrm{FBS}, 4 \mathrm{mM}$ L-glutamine, $1 \mathrm{mM}$ sodium pyruvate, $20 \mathrm{mM}$ HEPES and gentamicin $(50 \mu \mathrm{g} / \mathrm{ml})$. All cells were used in exponential growth phase. Harvesting, washings and centrifugation of cells were performed as described in [16].

\section{PHA-stimulated proliferation of lymphocytes}

Human peripheral blood lymphocytes were obtained by gradient centrifugation via HISTOPAQUE-1077 as described in [17] from blood of 9 healthy donors. Lymphocytes were washed twice in RPMI 1640 medium with following centrifugation at $1500 \mathrm{rpm}(200 \mathrm{~g})$ for 5 min (Elmi, Latvia). Then lymphocytes $\left(10^{6}\right.$ cells per $\left.\mathrm{ml}\right)$ were cultured in RPMI 1640 medium containing 10\% of pool human serum (AB group, IV), 0.01 M HEPES, glutamine (1\%) and gentamicin $(50 \mu \mathrm{g} / \mathrm{ml})$.
After counting in the Goryaev chamber lymphocytes were divided into two equal parts: for PHA stimulation and control test (without PHA).

PHA-stimulation of lymphocytes was carried out as described in [17]. For stimulation lymphocytes samples $\left(1 \times 10^{9}\right.$ cells $\left./ \mathrm{ml}\right)$ were used. To each of them $50 \mu \mathrm{g} / \mathrm{ml}$ of PHA was added and the lymphocytes were incubated for the 24,48 and $72 \mathrm{~h}$ at $37^{\circ} \mathrm{C}$ in $\mathrm{CO}_{2}$ incubator. Cell number was determined following cell clumps disaggregation by their passing to culture medium through a fine gauge needle with the addition of 1 mM EDTA. Cell viability was determined by trypan blue.

\section{Antibodies}

In our work we used monoclonal antibodies to protein B23 obtained in the Hematology Research Center, Russia (MAb 3C9 described in [18]), commercially available antibodies FC82291 (sc-56622, Santa Cruz Biotechnology, USA) and new antipeptide antibodies, obtained by us.

\section{Antipeptide antibodies}

Peptide synthesis: The following B23 fragments for induction of antipeptide antibodies were synthesized: N-terminal fragment (19-36 FGCELKADKDYHFKVDND), containing in all B23 forms and C-terminal fragment (283-294 AIQDLWQWRKSL), containing only in isoform B23.1. Shortened fragment (288-294 WQWRKSL) was synthesized for affinity chromatography of antibodies received against peptide (283-294) (numeration is given according to SwissProt: P06748.2). Peptides were synthesized by the solid-phase Fmocchemistry as described in [19]. The homogeneity of the peptides was estimated by analytical reverse-phase HPLC chromatography, amino acid and MALDI mass spectrometry analysis. Peptides (19-36) and (283-294) were conjugated with a carrier protein KLH for rabbit immunization or with OVA for ELISA as described in [19].

Rabbit immunization and ELISA: Rabbits were immunized at 5-6 week intervals with $1 \mathrm{mg}$ of the conjugated peptides emulsified in CFA (first injection) and in IFA (second and third injections) subcutaneously into six points. Third injection was performed with decreased to $0.5 \mathrm{mg}$ dose of peptide. Obtained rabbit antisera were tested in ELISA for their binding to corresponding peptides as described in [19]. For this, wells of a plate were coated with OVA-conjugated peptide and incubated with diluted sera (starting from dilution 1:40) followed by addition of secondary antibodies. Antibody titers were quantified by an end-point dilution approach (highest dilution of the sera with $\mathrm{OD}>0.1$ that is still positive). Sera against peptides (19-36) and (283-294) had titers 1:1320000 and 1:640000, correspondingly.

Purification of antibodies using affinity chromatography: Preparation of affinity adsorbent was carried out as described in [19]. For this $1 \mathrm{mg}$ of peptide (19-36) or (288-294) was dissolved in $1 \mathrm{ml}$ of $0.1 \mathrm{M} \mathrm{NaHCO}_{3}$ ( $\mathrm{pH} 8.3$ ) containing $0.5 \mathrm{M} \mathrm{NaCl}$, then was mixed with the $\mathrm{CNBr}$-activated Sepharose $4 \mathrm{~B}$ and gently rotated for $1 \mathrm{~h}$ at $20^{\circ} \mathrm{C}$. Not bound ligand was washed away and remaining active groups were blocked with solution of $0.2 \mathrm{M}$ Gly in $0.1 \mathrm{M} \mathrm{NaCl}(\mathrm{pH} 8.0)$ for $2 \mathrm{~h}$ at $20 \mathrm{oC}$. According to amino acid analysis data $1 \mathrm{ml}$ of sorbent contains $0.40 \mathrm{mg}$ of attached peptide (19-36) and $0.45 \mathrm{mg}$ of peptide (288-294). The affinity sorbent $(5 \mathrm{ml})$ was placed in a glass column and washed with $50 \mathrm{ml}$ of PBS (pH 7.4). Rabbit serum $(2 \mathrm{ml}$ ) against peptide (1936) or (283-294) was applied into the column for $1 \mathrm{~h}$. Sorbent was washed with $20 \mathrm{ml}$ of PBS. The specific antibodies were eluted with $0.1 \mathrm{M}$ glycine- $\mathrm{HCl}(\mathrm{pH} 2.2$ ) and the eluate was adjusted to $\mathrm{pH} 8.7$ with 1.5 M Tris- $\mathrm{HCl}$ buffer. The protein concentration of the samples was 
determined by UV absorbance $(280 \mathrm{~nm})$ and calculated in accordance with $\mathrm{c}(\mathrm{mg} / \mathrm{ml})=\mathrm{D} / 1.4(\mathrm{D}-$ optical density $)$.

\section{The extraction of nuclear proteins}

Nuclei from HeLa cells were isolated using NP-40 method described by Chan [13] and modified by us [15]. The isolated nuclei were incubated in ice-cold buffer $10 \mathrm{mM}$ Tris- $\mathrm{HCl}(\mathrm{pH} 7.4)$ for 15 min and centrifuged at $1720 \mathrm{~g}\left(4^{\circ} \mathrm{C}\right)$ for $10 \mathrm{~min}$ on $5804 \mathrm{R}$ centrifuge (Eppendorf, Germany). This procedure was repeated twice and supernatants were united.

\section{Immunofluorescence staining}

HeLa cells were grown on cover slips. Ramos, K-562 cells were washed out from the medium and placed on multitest slides covered with $0.1 \%$ poly-L-lysin. The slides were incubated in humid atmosphere at room temperature for $30 \mathrm{~min}$. Cells were treated with $0.5 \%$ Triton $\mathrm{X}-100$ in PBS for 5 min on ice followed by fixation with 2\% PFA in PBS for $20 \mathrm{~min}$ at room temperature. Fixed cells were washed in PBS twice for $10 \mathrm{~min}$ and incubated with primary antibodies for $30 \mathrm{~min}$ at room temperature. We used monoclonal antibodies in a dilution of 1:100, and antipeptide antibodies in a dilution 1:80. After washing the cells in PBS $(3 \times 10 \mathrm{~min})$ the secondary FITS- conjugated antibodies in a dilution 1:80 were applied for $30 \mathrm{~min}$. After washing with PBS samples were embedded in Mowiol. Cells were photographed with Photomicroscopes "Opton” or "Axiophot” (Carl Zeiss, Germany), using a Plan-Neofluar 100X objectives. For negative controls, PBS was used instead of the primary or secondary antibodies.

\section{Preparing samples for electrophoresis}

The cell suspensions were supplemented with PBS (in some cases with $\mathrm{RSB}$ or $10 \mathrm{mM}$ Tris- $\mathrm{HCl}(\mathrm{pH} 7.4)$ ) and glycerol to adjust the protein concentration in the sample to $\sim 1-1.5 \mathrm{mg} / \mathrm{ml}$ and the glycerol concentration to $30 \%$ before being treated with lysing solutions. Then to the samples lysing solution which contained SDS, EDTA and 2 -mercaptoethanol (2-ME) was added to the concentration of $5 \%$, $2.5 \%$, and $1 \mathrm{mM}$, respectively. The mixture was maintained at $100^{\circ} \mathrm{C}$ for $1 \mathrm{~min}$. The samples for "native" electrophoresis were processed under the conditions described in [13]: the cells were suspended in the lysing $10 \mathrm{mM}$ Tris- $\mathrm{HCl}$ buffer, $\mathrm{pH} 7.4$, containing $150 \mathrm{mM} \mathrm{KCl}, 1 \mathrm{mM}$ $\mathrm{MgCl} 2$, and $1 \mathrm{mM} \mathrm{DTT}$. The mixture was incubated at $37^{\circ} \mathrm{C}$ for 20 min followed by addition of 0.1 volume of the staining solution $(0.1 \%$ bromphenol blue in $50 \%$ glycerol). During the treatment of samples for electrophoresis by the Laemmli method [20], the cells were suspended in the lysing $62.5 \mathrm{mM}$ Tris- $\mathrm{HCl}$ buffer, $\mathrm{pH} 6.8$, containing 2\% SDS, $5 \%$ 2-ME, $10 \%$ glycerol, and $0.002 \%$ bromphenol blue and incubated at $100^{\circ} \mathrm{C}$ for $5 \mathrm{~min}$. Equal quantities of protein samples were used for electrophoretic analysis.

\section{SDS-PAGE and immunoblotting}

Electrophoresis was performed by the Laemmli method [20] at $12^{\circ} \mathrm{C}$. Electrotransfer was performed as described in [21] onto Immobilon-NC membranes for immunostaining or onto Immobilon-P membranes for sequencing, hydrolysis of C-terminal amino acid residues with carboxypeptidases and removing of acetyl protection from protein. The electrotransfer was done in $0.025 \mathrm{M}$ sodium bicarbonate buffer ( $\mathrm{pH} 9.0$ ), containing $20 \% \mathrm{CH}_{3} \mathrm{OH}$ and $0.1 \% \mathrm{SDS}$, at $12^{\circ} \mathrm{C}$ and constant current of $\sim 400 \mathrm{~mA}$ for $4 \mathrm{~h}$. For more efficient transfer of proteins with different molecular weights, a two-stage differentiated electrotransfer was used: the proteins with molecular weights $<60 \mathrm{kDa}$ (the lower region of the gel) were transferred for $3 \mathrm{~h}$, and the proteins with the higher molecular weights (the upper region of the gel) were transferred additionally for $12 \mathrm{~h}$. Immunostaining was performed with monoclonal or antipeptide antibodies in dilution 1:1000 and 1:500, correspondingly. The appropriate secondary antibodies were used in dilution 1:3000. DAB staining was performed as described in [16].

\section{Results and Discussion}

\section{Structural analysis of nucleophosmin in HeLa cells}

SDS-resistant oligomers, similar to oligomers discovered in hepatocellular carcinoma cells by Ulanet et al. [12] were revealed in cervical carcinoma cells (HeLa) by Chan [13] and by us [14] using immunochemical method. However, in majority of investigations only monome' $r$ s of nucleophosmin in HeLa cells were revealed by this method. What is the reason of such contradiction? We proposed that this contradiction could be due to at least three factors: to destruction of oligomers during sample treatment before electrophoresis, or to incomplete electrotransfer of oligomers, or to use of antibodies unable to detect the oligomers. We have studied the influence of these factors. The influence of different sample treatment is shown on Figure 1a. Treatment by standard Laemmli buffer: $62.5 \mathrm{mM}$ Tris- $\mathrm{HCl}$ buffer $(\mathrm{pH}$ 6.8 ), containing $2 \%$ SDS, $5 \% 2$-mercaptoethanol, $10 \%$ glycerol and $0.002 \%$ bromphenol blue [20], and heating $\left(100^{\circ} \mathrm{C}, 5 \mathrm{~min}\right)$ leaded to destruction of oligomers, only monomers are seen on blot (lane 1). Treatment by buffer without SDS, which was used by Chan [13], leaded to preservation of oligomers, but a large amount of protein remains on the start line (lane 2). We change conditions for sample treatment (see part "Materials and Methods").We found that introducing of glycerol
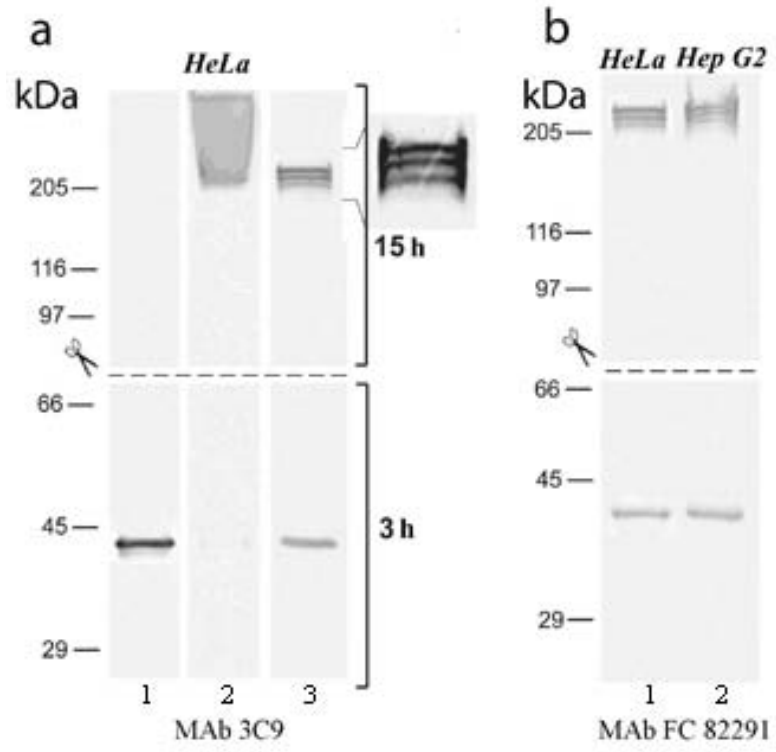

Figure 1: Effect of different sample treatment on the monomer-oligomer state of nucleophosmin in HeLa cells (a) and comparative analysis of the monomeroligomer state of nucleophosmin in HeLa and Hep G2 cells (b). a) Samples were treated under conditions: of traditional Laemmli method at $100^{\circ} \mathrm{C}$ for 5 $\min (1)$, of "native" electrophoresis at $37^{\circ} \mathrm{C}$ for $20 \mathrm{~min}(2)$, of our modification at $100^{\circ} \mathrm{C}$ for $1 \mathrm{~min}(3)$; b) HeLa (1) and Hep G2 (2) cells were treated in our modification at $100^{\circ} \mathrm{C}$ for $1 \mathrm{~min}$. SDS-PAGE was performed by the Laemmli method in $7.5 \%$ PAG. The proteins were electrotransferred in two stages. Here and in Figures 2-4 strokes show the lines of membrane section; MAb to protein B23 3C9 (a) and FC 82291 (b) were used for immunostaining; positions of marker proteins are shown on the left. 
before addition of lysing solution and shorter time heating $\left(100^{\circ} \mathrm{C}, 1\right.$ $\mathrm{min}$ ) lead to preservation of oligomers even in SDS-containing buffer (lane 3).

We found that electrotransfer under standard conditions (for 3-4 h) proved to be insufficient for the complete transfer of proteins with different molecular weights, in particular, nucleophosmin monomers (38-40 kDa) and oligomers (210-230 kDa) (data not shown). Therefore, we used two stage electrotransfer: the bottom part of the gel containing proteins with molecular weights of $<60 \mathrm{kDa}$ was blotted for $3 \mathrm{~h}$, while the top part of the gel with high molecular weight proteins was blotted for $15 \mathrm{~h}$. In our experiment the electrode buffer and the gel contained $0.1 \%$ SDS and the samples were treated in PBS containing $30 \%$ glycerol, $5 \%$ SDS, and $2.5 \% 2-\mathrm{ME}$ at $100^{\circ} \mathrm{C}$ for $1 \mathrm{~min}$. One band corresponding to the monomeric form and three bands corresponding to the oligomeric forms of nucleophosmin were detected under this treatment on immunoblots. The oligomeric forms were most prevalent (Figure 1a, lane 3). It should be noted that these oligomers have the same molecular weights (210-230 kDa) as oligomers, detected in HeLa cells by "native" electrophoresis, where sample buffer did not contain SDS [13] and in Hep G2 cells by SDS-PAGE, where sample buffer with reducing amount (to $0.1 \%$ ) of SDS was used [12]. Using our modified method it was shown that HeLa and Hep G2 cells had similar sets of nucleophosmin oligomeric forms (Figure 1b).

The lack of information about role of monomers and oligomers of nucleophosmin in tumor cells is due to absence of antibodies which can selectively detect these protein forms. Majority of 20 described antibodies are able to detect only monomers and they are not able to detect oligomers or their ability to detect them was not investigated. Only three antibodies [12,13,18] detected both monomers and oligomers, but without selectivity. Two of them we used in our work (3C9 and FC 82291). These antibodies gave the same information about monomer-oligomer state of nucleophosmin in HeLa cells (Figure 1a, b). The antibodies against individual isoforms of nucleophosmin were not described.

To test the assumption of Ulanet [12] that SDS-resistant oligomers appearance connected with truncation of nucleophosmin, we conducted direct structural analysis of nucleophosmin in HeLa cells. Taking into account probable existence of several nucleophosmin forms and nucleoplasma-nucleolus localization of them, we decided to assess nucleophosmin state not in the nucleoli but in the nuclei of HeLa cells. The nuclei were isolated by the method described in [13] using hypotonic RSB buffer (10 mM Tris- $\mathrm{HCl}$ (pH 7.4), $10 \mathrm{mM} \mathrm{NaCl}$, $1.5 \mathrm{mM} \mathrm{MgCl} 2$ ). Namely this method was used to obtain HeLa nuclei for subsequent isolation and proteomic analysis of nucleoli, where only B23.1 isoform beginning from Met1 was detected [22,23].

We first observed that exposure of the cells in RSB buffer leads to decomposition of oligomers and to appearance of a low molecular weight band in the zone of monomers (Figure 2a, lane 2). The analogous band doublet was detected in the fraction of isolated nuclei incubated in RSB (lane 3). We also found that following treatment of obtained nuclei with $10 \mathrm{mM}$ Tris- $\mathrm{HCl}(\mathrm{pH}$ 7.4) resulted in substantial swelling of the nuclei accompanied by protein washout. Electrophoretic analysis showed that the supernatant fraction (Figure 2b, lane 3) has nine most intensely Coomassie stained protein bands, two of which (4 and 5) contained nucleophosmin according to immunostaining (Figure $2 \mathrm{c}$, lane 3). The following nine proteins were identified by MALDI-MS analysis of tryptic peptides in the supernatant: vimentin, keratin-8, $\beta / \gamma$-actin, nucleophosmin, GAPDH, hnRNP A2/B1, and histones $\mathrm{H} 2 \mathrm{~A}, \mathrm{H} 2 \mathrm{~B}$, and $\mathrm{H} 4$ [24]. At the same time, the quantity of B23 in the pellet (in the nuclei) considerably decreased after treatment and the only one high molecular weight monomer band (Figure $2 \mathrm{c}$, lane 2 ) corresponding to nucleophosmin form remaining tightly bound to the nucleolar structures was detected.
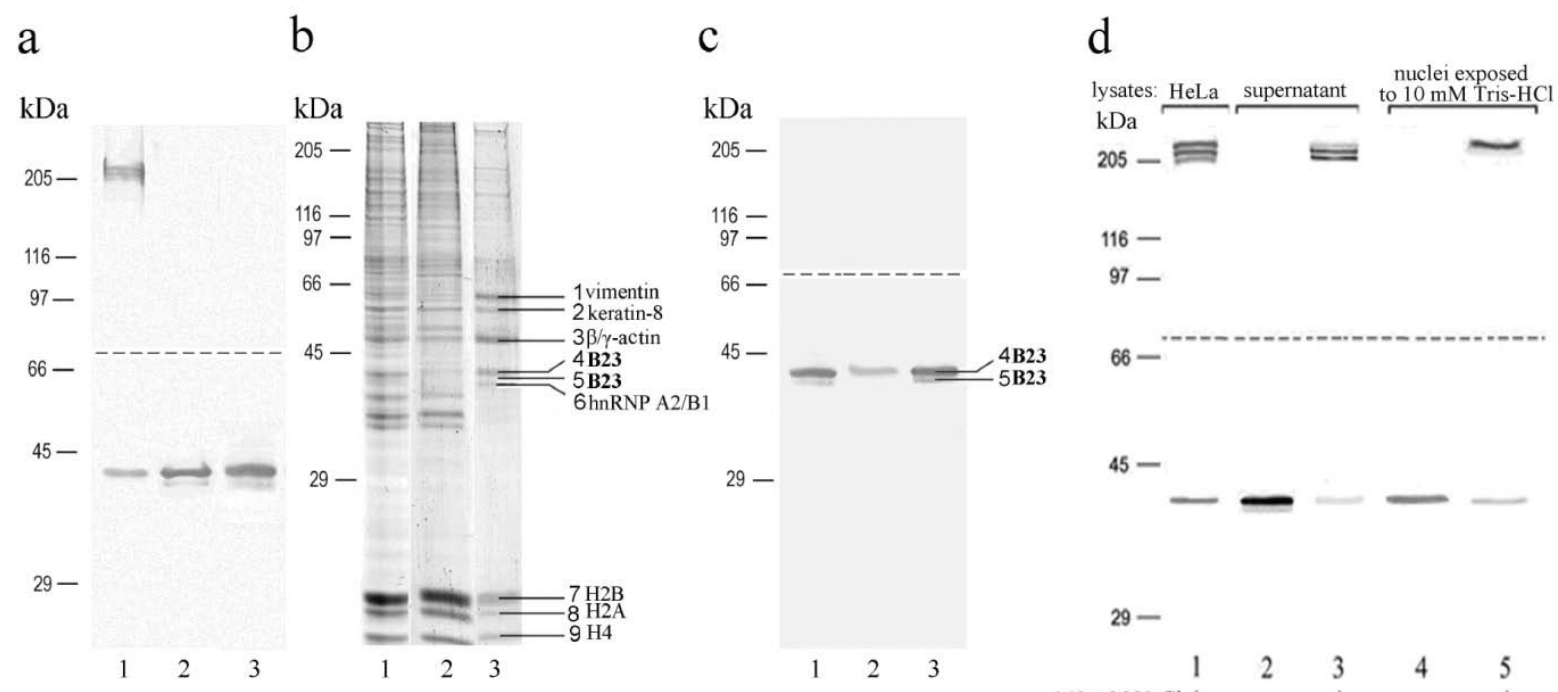

igure 2: Immunochemical (a, c, d) and electrophoretic (b) analysis of the influence of hypotonic treatment of HeLa cells (a) and nuclei (c, d) on state of nucleophosmin. a) HeLa cells in PBS (1), RSB (2), nuclei in RSB (3); b , c) nuclei in RSB (1), fraction of nuclei (2) and supernatant (3) after extraction with 10 mM Tris-HCl; d) HeLa cells (1), fractions of supernatant and nuclei were kept in $10 \mathrm{mM}$ Tris- $\mathrm{HCl}(2,4)$, or in $10 \mathrm{mM}$ Tris- $\mathrm{HCl}$, containing $140 \mathrm{mM} \mathrm{NaCl}(3$, 5). Samples were treated for electrophoresis in buffers (PBS, RSB, or $10 \mathrm{mM}$ Tris- $\mathrm{HCl}$ ) containing $30 \%$ glycerol by lysing solution at $100^{\circ} \mathrm{C}$ for 1 min. SDS-PAGE was performed by the Laemmli method in $7.5 \%$ PAG. The proteins were electrotransferred in two stages. Positions of the nine protein bands of supernatant fraction more intensively stained with Coomassie G-250 are shown on the right (b); the two of them (4 and 5) contained nucleophosmin (c, lane 3). 
The detailed structural analysis of nucleophosmin extracted from the nuclei was carried out. We developed a method for identification of structurally close isoforms B23.1 and B23.2 based on the analysis of their C-terminal sequences using carboxypeptidase hydrolysis [15] and showed that protein band 4 contained only isoforms B23.1, and band 5 contained isoform B23.2. We also demonstrated that nucleophosmin N-terminus is blocked by acetyl group. Deacetylation of nucleophosmin allowed us to carry out its sequencing and to establish that the $\mathrm{N}$-terminus of isoforms is truncated by nine amino acid residues.

We have investigated possibility of formation of the SDS-stable oligomers from truncated forms. The addition of $\mathrm{NaCl}$ up to $140 \mathrm{mM}$ into samples of supernatant and nuclei in $10 \mathrm{mM}$ Tris- $\mathrm{HCl}$ buffer leaded to formation of oligomers from monomers. Western-blot analysis (Figure 2d) showed that nucleophosmin is detected only as monomers in the supernatant and in the nuclear pellet fractions treated with 10 $\mathrm{mM}$ Tris- $\mathrm{HCl}$ ( $\mathrm{pH}$ 7.4) (lanes 2 and 4). Different sets of oligomers were formed from these fractions on addition of $\mathrm{NaCl}$ (lanes 3 and 5). In supernatant the two most intense bands were corresponded to the bands of low molecular weight oligomers which were detected in the HeLa cell lysate (line 1). However, the high molecular weight oligomer band absent in supernatant was dominated in the treated nuclei sample. Thus, it has been shown that truncated nucleophosmin does produce SDS-resistant oligomers, but their set does not correspond to the complete set of oligomers observed in the cell lysates. Most probably, the two pools of nucleophosmin (extractable and not extractable) are structurally different. This fact is confirmed by literature data where in the nucleoli of HeLa cells tryptic peptide of nucleophosmin beginning from Met1 was detected by MALDI-MS [22,23].

\section{Analysis of nucleophosmin in human tumor cell cultures and normal rat tissues}

For analysis of the structural state of nucleophosmin in different tumor cells and normal rat tissues we used immunoblotting scheme developed by us for concurrent detection and semiquantitative evaluation of monomeric and oligomeric B23 forms in HeLa cells [15]. According to the immunoblot analysis (Figure 3) remarkable differences were observed: 1) the content of protein B23 in normal rat tissues (liver, kidney, lung, heart) was significantly lower than in human tumor cells and actively proliferating mouse NIH/3T3 cells; 2 ) SDS-stable oligomeric forms of nucleophosmin were observed in all investigated human tumor cells and mouse $\mathrm{NIH} / 3 \mathrm{~T} 3$ cells, the number of these forms and their electrophoretic mobility varied (a); 3) SDSstable oligomeric forms of nucleophosmin were not detected in normal rat tissues (b), including the most enriched in protein B23 liver tissue (b, lane 5) and isolated from its nuclei (b, lane 6). Thus, in normal tissues protein B23 was detected only in monomeric form whereas in neoplastic cells it was detected both in monomeric and in specific SDSresistant oligomeric forms under the same conditions. It might indicate the existence of conformationally distinct nucleophosmin forms in tumor cells. These findings are entirely consistent with the data on the state of the protein B23 in tumor and normal liver tissues [12]. So, for the first time we have demonstrated that not only overexpression but also formation of nucleophosmin SDS-stable oligomeric forms is a common feature of tumor and actively proliferating cells. It became apparent that detection of oligomeric forms of nucleophosmin may be important for the diagnosis of tumors.

\section{Antipeptide antibodies as instrument for the specific detection of monomeric and oligomeric forms of nucleophosmin in tumor cells}

We decided to create antibodies for the specific detection of monomeric and oligomeric forms of nucleophosmin with using of its synthetic fragments. First of all we carried out the revision of structures of different nucleophosmin forms for the selection of antigenic sites. We found that $\mathrm{N}$-terminal part of nucleophosmin which contains residues from 1 to 117 (oligomerization domain) is a common part for all known forms of nucleophosmin including two isoforms, its mutant and fused forms [2,3]. It is known that residues Tyr-17, Leu-18, Phe-31, a

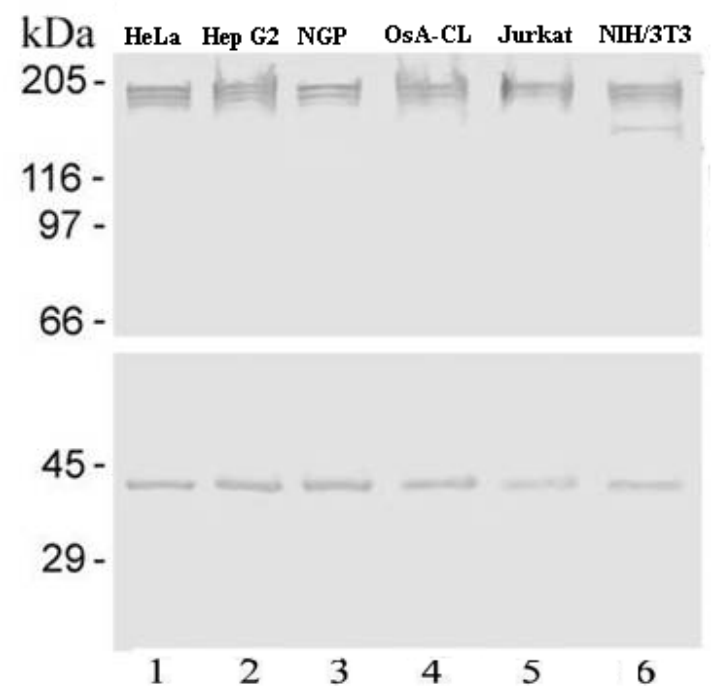

b

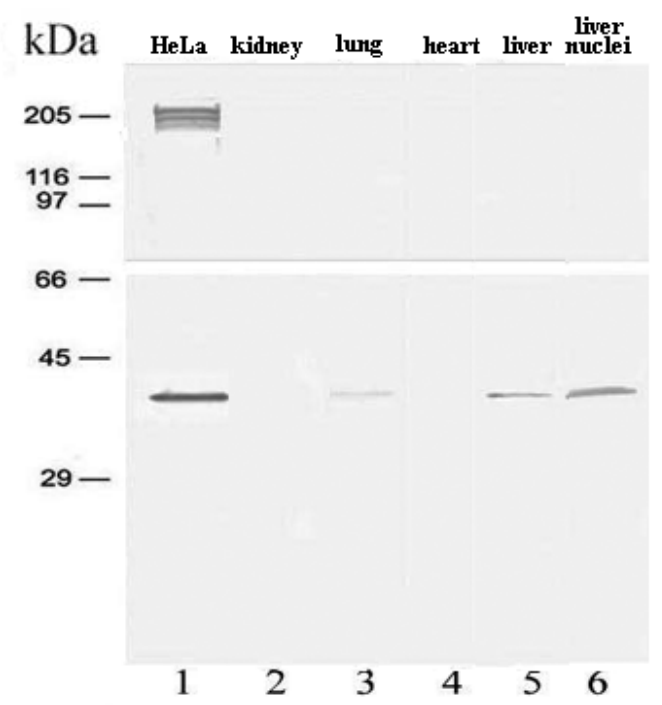

Figure 3: Immunochemical analysis of nucleophosmin in different human tumor cells and mouse fibroblast cells NIH/3T3 (a) rat normal tissues and liver nuclei (b) Electrophoresis was performed in 7.5\% (a) and 10\% (b) PAG. For immunostaining MAb FC 82291 was used. 
Citation: Vladimirova NM, Pisareva MA, Zharskaya OO, Deineko NL, Bulycheva TI, et al. (2011) Tumor Specific Oligomeric Forms of Nucleophosmin JJ Cancer Sci Ther 3: 205-212. doi:10.4172/1948-5956.1000090

His-40 are involved directly in intermolecular contacts in oligomers $[2,3,25]$. We proposed that antibodies directed to fragment from $\mathrm{N}$-terminal region (19-36) which is involved in intermolecular contacts in oligomers will not bind with oligomeric forms of nucleophosmin, but will interact only with its monomeric forms. It is known also that isoform B23.1 is a major form in tumor cells, it is included in all known heterooligomers and its C-terminal region containing residues (283294) is exposed on the surface of both oligomers and monomers [9]. Therefore we proposed that antibodies directed to this region can be used as an instrument for the detection of B23.1 monomer and for the detection of all known oligomers. Synthetic peptides corresponding to N-terminal fragment (19-36 FGCELKADKDYHFKVDND) and to C-terminal fragment of isoform B23.1 (283-294 AIQDLWQWRKSL) were used for rabbit immunization. As result the affinity purified antibodies against peptide (19-36) (Ab (19-36)) with concentration $0.46 \mathrm{mg} / \mathrm{ml}$ and titer 1:64000 and antibodies against peptide (283-294)
(Ab (283-294)) with concentration $0.63 \mathrm{mg} / \mathrm{ml}$ and titer 1:32000 were obtained from rabbit sera.

Investigation of the specificity of obtained antibodies was carried out by immunochemical method with using human tumor cells HeLa, Hep G2, Ramos and K-562 (Figure 4, a-c). In all tumor cells in contrast to monoclonal antibodies 3C9 recognizing both monomers and oligomers of nucleophosmin (a) Ab (19-36) detected only monomers (b), whereas Ab (283-294) detected presumably oligomers (c). So our suggestion that $\mathrm{Ab}$ (19-36) are specific for monomers proved true. On our opinion may be two interpretations of results of immunostaining with Ab (283-294): first, these antibodies can not detect monomers, and second, isoform B23.1 is fully incorporated into the oligomers. To check the ability of these antibodies to detect monomers we used supernatant fraction (described in previous part) containing monomers of isoforms B23.1 and B23.2. Based on immunochemical analysis of supernatant fraction (d) we can make important conclusions: Ab (19-36) are able a

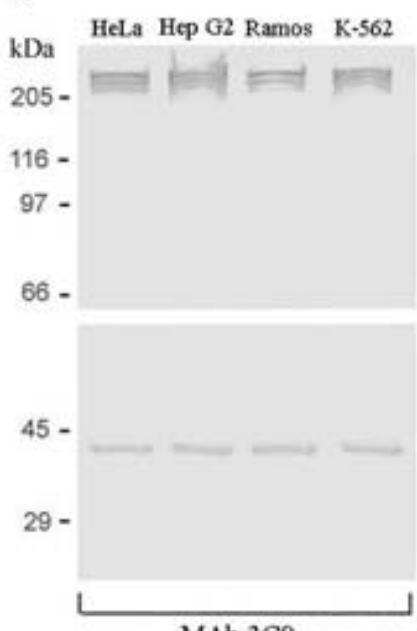

b

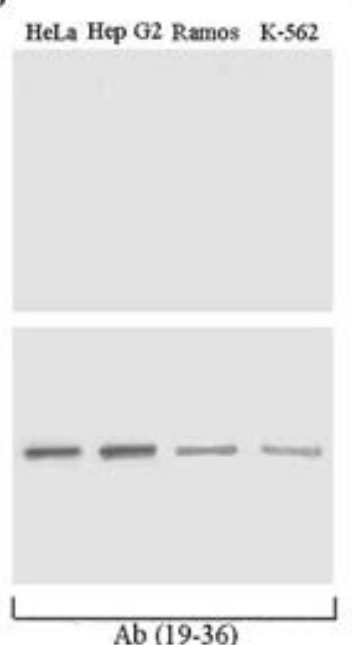

c

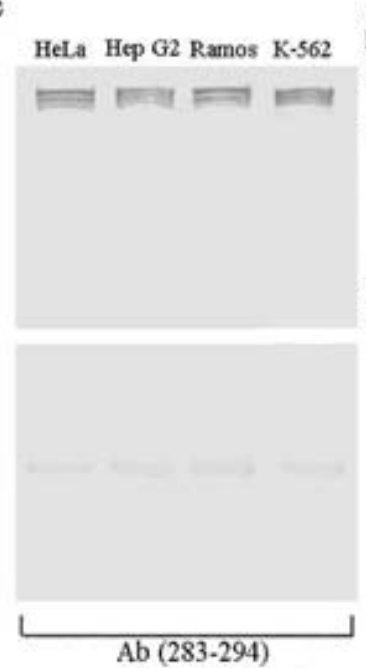

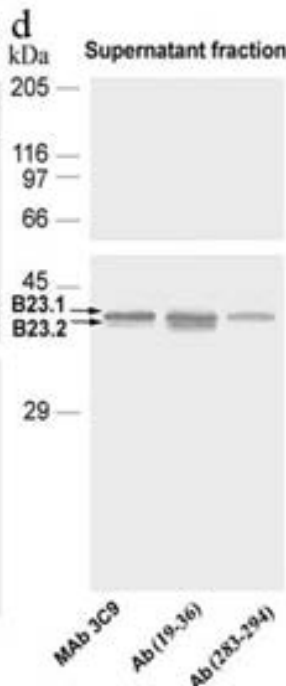

Figure 4: Immunochemical analysis of specificity of MAb $3 C 9$ (a), Ab (19-36) (b) and Ab (283-294) (c). Tumor cells (a-c) and supernatant fraction obtained after nuclei treatment (d) were used. SDS-PAGE was performed by the Laemmli methods in $7.5 \%$ (a-c) and $10 \%$ PAG (d). Samples were treated as described on legend to Figure $1 \mathrm{~b}$.
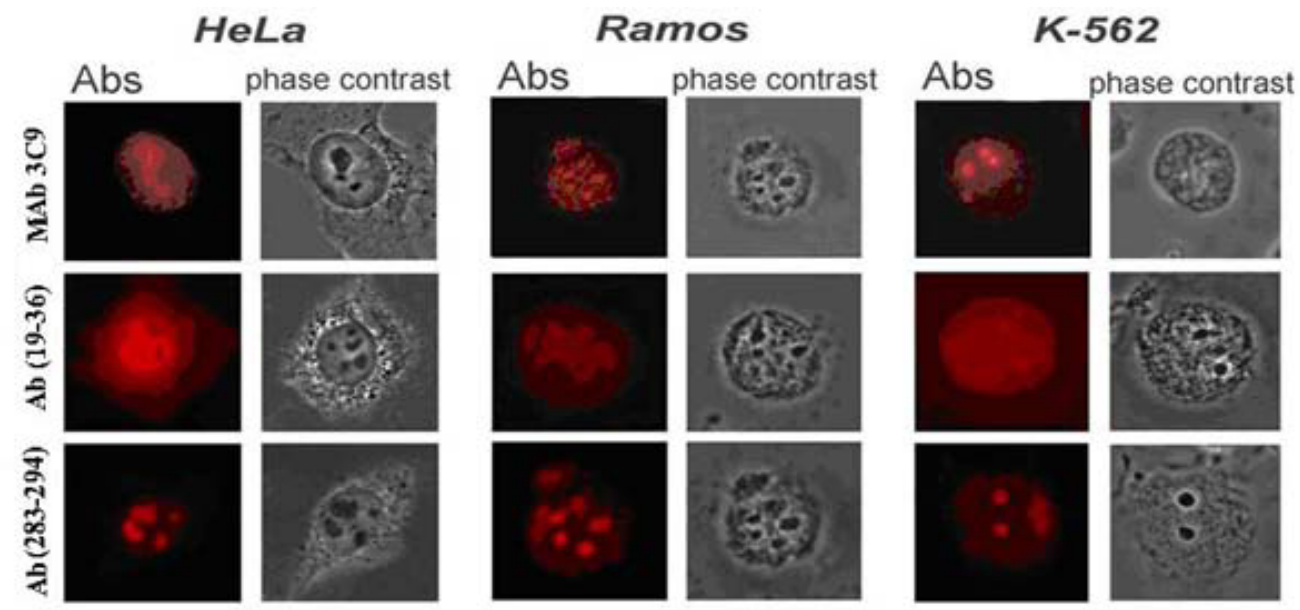

Figure 5: Immunocytochemical analysis of nucleophosmin in HeLa, Ramos and K-562 cells with use of MAb 3C9, Ab (19-36) and Ab (283-294). 


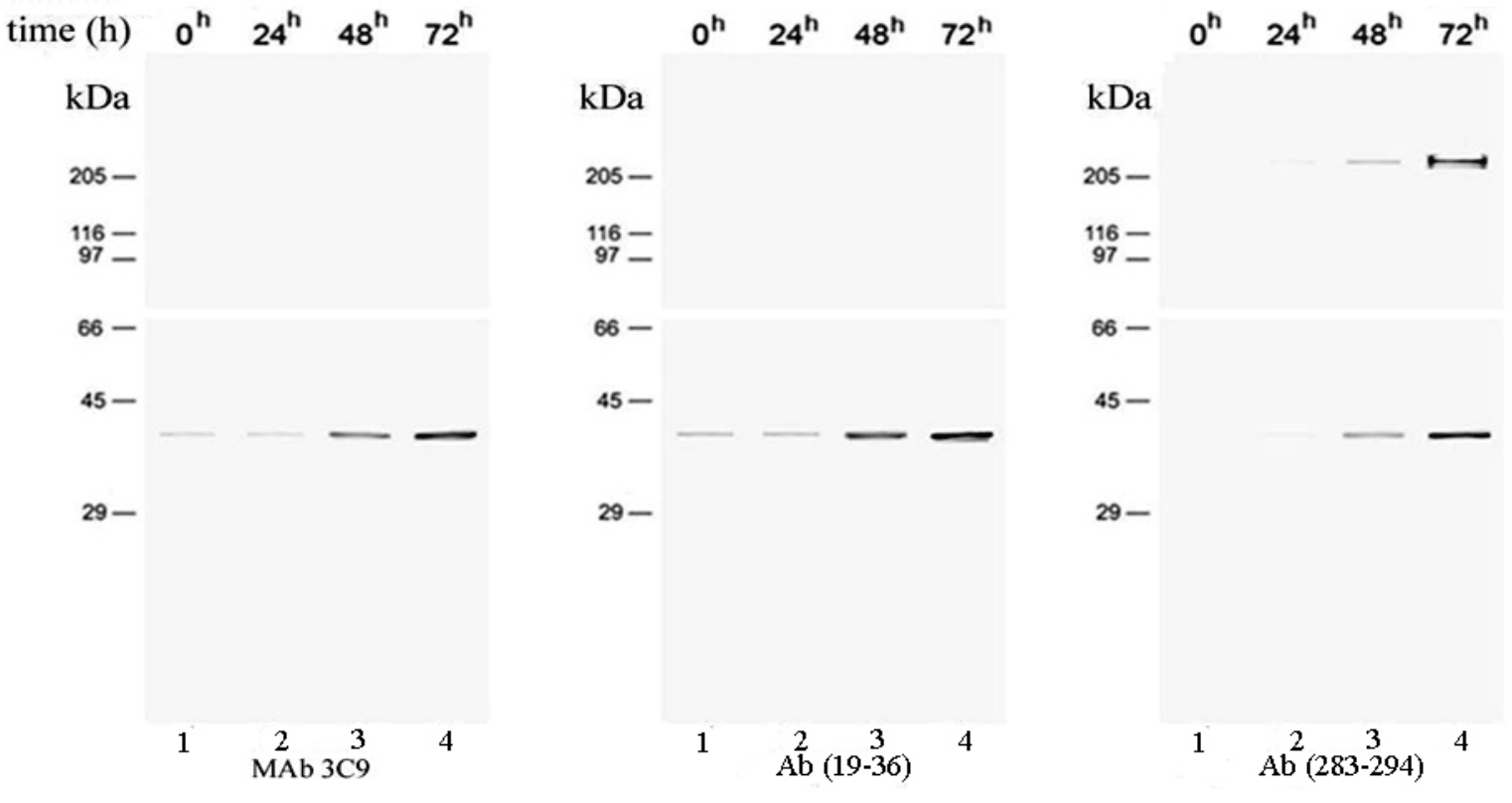

Figure 6: Immunochemical analysis of nucleophosmin with Mab 3C9, Ab (19-36) and Ab (283-294) in human PHA-stimulated lymphocytes.

to detect two isoforms, but stronger than monoclonal antibodies; $\mathrm{Ab}$ (283-294) are able to detect monomers of B23.1 isoform. Therefore the second interpretation is true: in tumor cells most of the B23.1 isoform is included into the oligomers.

We carried out immunocytochemical analysis of nucleophosmin in tumor cells HeLa, Ramos and K-562 (Figure 5). Control monoclonal antibodies 3C9 gave weak staining of the nucleoplasm and bright staining of the nucleoli in all examined cells. It was shown that Ab (1936) not stained the nucleoli, but stained the cytoplasm and nucleoplasm. In contrast to them $\mathrm{Ab}$ (283-294) gave a strong staining of the nucleoli.

Very important conclusions can be made from the results of immunocytochemical and Western-blot analysis of different human tumor cells. The antibodies directed to the $\mathrm{N}$-terminal part (19-36) of nucleophosmin detected only monomers which are localized in the nucleoplasm and in the cytoplasm, while the antibodies directed to the C-terminal part (283-294) of B23.1 isoform detected only oligomers which are localized in the nucleoli.

\section{Nucleophosmin as a marker of proliferation activity of human peripheral lymphocytes}

In our earlier study [17] with the use of the MAb 3C9 it was shown that PHA stimulation of lymphocytes resulted in a gradual increase in the protein B23 content which was at the maximum after $48-72^{\mathrm{h}}$ when majority of the cells undergoing the S-phase. It was shown also that changes in B23 content and its localization occurred before an appearance of Ki-67 protein - traditional marker of proliferation. Unfortunately in that work only monomers of nucleophosmin were investigated. We decided not only to determine the content of protein B23 in lymphocytes stimulated to proliferation by PHA but also to evaluate the changes of its monomer-oligomer state. We carried out PHA-stimulation as described in our work [17]. In this investigation for revealing of oligomers and evaluation of changes in monomer-oligomer state of nucleophosmin during PHA-stimulation of lymphocytes we used besides MAb 3C9 new antipeptide antibodies for immunochemical analysis (Figure 6). Immunochemical analysis performed with using of three antibodies allowed to show not only dramatically increasing of nucleophosmin content during $48-72^{\mathrm{h}}$ PHA-treatment but also that this increasing is due to overexpression of isoforms B23.1 which was detected by all three antibodies but specifically detected by Ab (283-294). 48-72 ${ }^{\mathrm{h}}$ PHA-treatment resulted in appearance of SDS-resistant oligomer(s), containing B23-1 isoform. So, SDS-resistant oligomers of protein B23 can be used as markers of proliferating activity of lymphocytes, and $\mathrm{Ab}$ (283-294) can be used as instrument for their detection.

Based on obtained data we can conclude that existence of SDSresistant oligomers containing abnormal nucleophosmin forms is a common feature of tumor cells. Detection of these oligomers and investigation of their properties may be useful for diagnostic of cancer and for creation of target-specific therapy instruments.

None of the authors have any conflicts of interest.

\section{Funding}

This work was supported by the gtants of the Russian Foundation for Basic Research (project No. 09-04-00713-a) and of the Program "Fundamental Sciences for Medicine-2011".

\section{References}

1. Mattern KA, Humbel BM, Muijsers AO, de Jong L, van Driel R (1996) hnRNP proteins and B23 are the major proteins of the internal nuclear matrix of HeLa S3 cells. J Cell Biochem 62: 275-289.

2. Lim MJ, Wang XW (2006) Nucleophosmin and human cancer. Cancer Detect Prev 30: 481-490.

3. Grisendi S, Mecucci C, Falini B, Pandolfi PP (2006) Nucleophosmin and cancer. Nat Rev Cancer 6: 493-505.

4. Brady SN, Yu Y, Maggi LB Jr, Weber JD (2004) ARF impedes NPM/B23 shuttling in an Mdm2-sensitive tumor suppressor pathway. Mol Cell Biol 24 9327-9338. 
Citation: Vladimirova NM, Pisareva MA, Zharskaya OO, Deineko NL, Bulycheva TI, et al. (2011) Tumor Specific Oligomeric Forms of Nucleophosmin JJ Cancer Sci Ther 3: 205-212. doi:10.4172/1948-5956.1000090

Page 212 of 8

5. Namboodiri VM, Akey IV, Schmidt-Zachmann MS, Head JF, Akey CW (2004) The structure and function of Xenopus NO38-core, a histone chaperone in the nucleolus. Structure 12: 2149-2160.

6. Herrera JE, Correia JJ, Jones AE, Olson MO (1996) Sedimentation analyses of the salt- and divalent metal ion-induced oligomerization of nucleolar protein B23. Biochemistry 35: 2668-2673.

7. Negi SS, Olson MO (2006) Effects of interphase and mitotic phosphorylation on the mobility and location of nucleolar protein B23. J Cell Sci 119: 3676-3685.

8. Okuwaki M (2008) The structure and functions of NPM1/Nucleophsmin/B23, a multifunctional nucleolar acidic protein. J Biochem 143: 441-448.

9. Falini B, Mecucci C, Saglio G, Lo Coco F, Diverio D, et al. (2008) NPM1 mutations and cytoplasmic nucleophosmin are mutually exclusive of recurrent genetic abnormalities: a comparative analysis of 2562 patients with acute myeloid leukemia. Haematologica 93: 439-442.

10. Grummitt CG, Townsley FM, Johnson CM, Warren AJ, Bycroft M (2008) Structural consequences of nucleophosmin mutations in acute myeloid leukemia. J Biol Chem 283: 23326-23332.

11. Castro IP, Carcer G, Malumbres M (2007) A census of mitotic cancer genes: new insights into tumor cell biology and cancer therapy. Carcinogenesis 28 : 899-912.

12. Ulanet DB, Torbenson M, Dang CV, Carciola-Rosen C, Rosen A (2003) Unique conformation of cancer autoantigen B23 in hepatoma: A mechanism for specificity in the autoimmune response. PNAS 100: 12361-12366.

13. Chan PK, Chan FY (1995) Nucleophosmin/B23 (NPM) oligomer is a major and stable entity in HeLa cells. Biochim Biophys Acta 1262: 37-42.

14. Vadimirova NM, Sautkina EN, Tabdanov ED, Bulycheva TI, Ovchinnikova TV, et al. (2004) Revealing and characterization of monomeric and oligomeric forms of a nucleolar protein B23/nucleophosmin in HeLa cells. Biol Membr (Moscow) 24: 94-101.

15. Vladimirova NM, Lobanova NV, Potapenko NA (2010) State of Oncomarker
Protein B23/Nucleophosmin in HeLa Cells. Biochemistry (Mosc) 75: 851-860.

16. Sautkina EN, Potapenko NA, Vladimirova NM (2006) State of nucleolar proteins B23/nucleophosmin and UBF in HeLa cells during apoptosis induced by tumor necrosis factor. Biochemistry (Mosc). 71: 634-643.

17. Dergunova NN, Bulycheva TI, Artemenko EG, Shpakova AP, Pegova AN, e al. (2002) A major nucleolar protein B23 as a marker of proliferation activity of human peripheral lymphocytes. Immunol Lett 83: 67-72.

18. Bulycheva TI, Dergunova NN, Artemenko EG, Dudnik OA, Shpakova AP, et al. (2000) Analysis of the proliferative activity of a cell using new monoclonal antibodies to nucleolar protein B23/nucleophosmin. Tsitologiya 42: 944-954.

19. Shalgunov VS, Lobanova NV, Bulycheva TI, Deineko NL, Volkova TD, et al (2009) Antibodies to synthetic fragments of nucleophosmin for the specific detection of its monomeric and oligomeric forms. Russ J Bioorg Chem (Eng Transl) 35: 720-727

20. Laemmli UK (1970) Cleavage of structural proteins during the assembly of the head of bacteriophage T4. Nature 227: 680-685.

21. Vladimirova NM, Potapenko NA, Sachs G, Modyanov NN (1995) Determination of the sidedness of the carboxy-terminus of the $\mathrm{Na}+/ \mathrm{K}(+)$ ATPase alpha-subunit using lactoperoxidase iodination. Biochim Biophys Acta 1233: 175-184.

22. Andersen JS, Lyon CE, Fox AH, Leung AK, Lam YW, et al. (2002) Directed proteomic analysis of the human nucleolus. Curr Biol 12: 1-11.

23. Scherl A, Couté Y, Déon C, Callé A, Kindbeiter K, et al. (2002) Functiona proteomic analysis of human nucleolus. Mol Biol Cell 13: 4100-4109.

24. Sautkina EN, Potapenko NA, Bulycheva TI, Vladimirova NM (2008) Isolation of the protein B23/nucleophosmin from HeLa cell nuclei. Prikl Biokhim Mikrobio 44: $287-295$

25. Qi W, Shakalya K, Stejskal A, Goldman A, Beeck S, et al. (2008) NSC348884, a nucleophosmin inhibitor disrupts oligomer formation and induces apoptosis in human cancer cells. Oncogene 27: 4210-4220. 